Prepared in cooperation with The Nature Conservancy Global Freshwater Program

\title{
Monitoring and Evaluation of Environmental Flow Prescriptions for Five Demonstration Sites of the Sustainable Rivers Project
}

Open-File Report 2010-1065 



\section{Monitoring and Evaluation of Environmental Flow Prescriptions for Five Demonstration Sites of the Sustainable Rivers Project}

By C.P. Konrad

Prepared in cooperation with The Nature Conservancy Global Freshwater Program

Open-File Report 2010-1065

U.S. Department of the Interior

U.S. Geological Survey 


\title{
U.S. Department of the Interior \\ KEN SALAZAR, Secretary
}

\author{
U.S. Geological Survey \\ Marcia K. McNutt, Director
}

U.S. Geological Survey, Reston, Virginia: 2010

\begin{abstract}
For more information on the USGS-the Federal source for science about the Earth, its natural and living resources, natural hazards, and the environment, visit http://www.usgs.gov or call 1-888-ASK-USGS.

For an overview of USGS information products, including maps, imagery, and publications, visit $h$ ttp://huw.usgs.gov/pubprod
\end{abstract}

To order this and other USGS information products, visit http://store.usgs.gov

Suggested citation:

Konrad, C.P., 2010, Monitoring and evaluation of environmental flow prescriptions for five demonstration sites of the Sustainable Rivers Project: U.S. Geological Survey Open-File Report 2010-1065, 22 p.

Any use of trade, product, or firm names is for descriptive purposes only and does not imply endorsement by the U.S. Government.

Although this report is in the public domain, permission must be secured from the individual copyright owners to reproduce any copyrighted material contained within this report. 


\section{Contents}

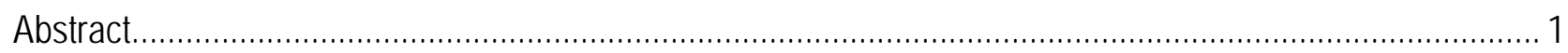

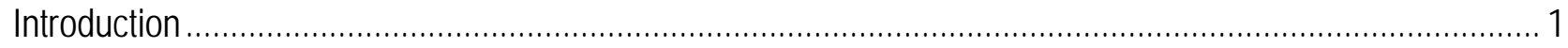

Demonstration Sites with Implemented Environmental Flows in the Sustainable River Project....................... 2

Green River Dam, Green River, Kentucky ................................................................................. 2

Thurmond Dam, Savannah River, Georgia and South Carolina........................................................ 3

Bill Williams River, Arizona .................................................................................................... 4

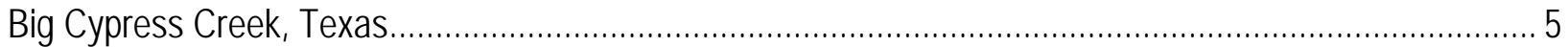

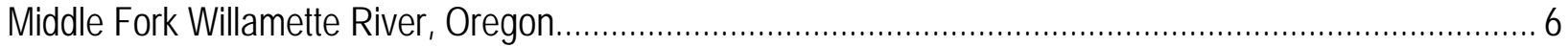

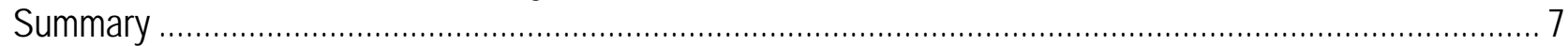

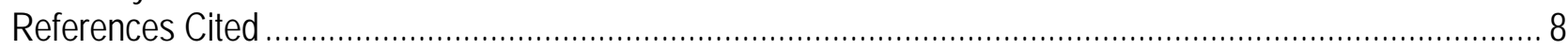

\section{Figures}

Figure 1. Map of five demonstration sites with implemented environmental flow prescriptions as part of the the Sustainable Rivers Project 10

Figure 2. Median monthly mean streamflow prior to regulation for the Green River at Munfordville, Kentucky (USGS station 03308500), with minimum and maximum monthly mean streamflow. 10

Figure 3. Median monthly mean streamflow prior to regulation for the Savannah River at Augusta, Georgia (USGS station 02197000), with minimum and maximum monthly mean streamflow 11 Figure 4. Median monthly mean streamflow prior to regulation for the Bill Williams River downstream of the Alamo dam site, Arizona (USGS station 09426000), with minimum and maximum monthly mean streamflow.

Figure 5. Median monthly mean streamflow prior to regulation for Big Cypress Creek near Jefferson, Texas (USGS station 07346000), with minimum and maximum monthly mean streamflow ..... 12

Figure 6. Median monthly mean streamflow prior to regulation for Middle Fork Willamette River near Dexter, Oregon (USGS station 14150000), with minimum and maximum monthly mean streamflow.... 12

\section{Tables}

Table 1. Streamflow information downstream of five demonstration sites in the Sustainable Rivers Project.. 13 Table 2. U.S .Army Corps of Engineers Dams in the Sustainable Rivers Project that have implemented environmental flow prescriptions 14

Table 3. Environmental flow prescriptions at five demonstration sites in the Sustainable Rivers Project........ 14

Table 4. Investigations that support monitoring and evaluation of environmental flow prescriptions at demonstrations sites of the Sustainable Rivers Project. 


\section{Conversion Factors}

\section{SI to Inch/Pound}

\begin{tabular}{lcl}
\hline \multicolumn{1}{c}{ Multiply } & By & \multicolumn{1}{c}{ To obtain } \\
\hline Length & \\
\hline kilometers $(\mathrm{km})$ & 0.6214 & mile $(\mathrm{mi})$ \\
\hline square kilometer $\left(\mathrm{km}^{2}\right)$ & 247.1 & acre \\
\hline cubic meter per second $\left(\mathrm{m}^{3} / \mathrm{s}\right)$ & Flow rate & \\
\hline & 35.31 & cubic foot per second $\left(\mathrm{ft}^{3} / \mathrm{s}\right)$ \\
\hline cubic meter $\left(\mathrm{m}^{3}\right)$ & Volume & \\
\hline
\end{tabular}




\title{
Monitoring and Evaluation of Environmental Flow Prescriptions for Five Demonstration Sites of the Sustainable Rivers Project
}

\author{
By Christopher P. Konrad ${ }^{1}$
}

\begin{abstract}
The Nature Conservancy has been working with U.S. Army Corps of Engineers (Corps) through the Sustainable Rivers Project (SRP) to modify operations of dams to achieve ecological objectives in addition to meeting the authorized purposes of the dams. Modifications to dam operations are specified in terms of environmental flow prescriptions that quantify the magnitude, duration, frequency, and seasonal timing of releases to achieve specific ecological outcomes. Outcomes of environmental flow prescriptions implemented from 2002 to 2008 have been monitored and evaluated at demonstration sites in five rivers: Green River, Kentucky; Savannah River, Georgia/South Carolina; Bill Williams River, Arizona; Big Cypress Creek, Texas; and Middle Fork Willamette River, Oregon. Monitoring and evaluation have been accomplished through collaborative partnerships of federal and state agencies, universities, and nongovernmental organizations.
\end{abstract}

\section{Introduction}

The Nature Conservancy has been working with U.S. Army Corps of Engineers (Corps) through the Sustainable Rivers Project (SRP) to modify operations of dams to achieve ecological objectives in addition to meeting the authorized purposes of the dams. The modification of dam operations, or re-operation of the dam, is based on environmental flow prescriptions, which specify the characteristics of streamflow needed for a desired ecological outcome or response. As of 2009, as part of the SRP, environmental flow prescriptions have been developed and implemented to some extent at five demonstration sites around the United States (table 1): Green River, Kentucky; Savannah River, Georgia/South Carolina; Bill Williams River, Arizona; Big Cypress Creek, Texas; and Middle Fork Willamette River, Oregon. These prescriptions address riverine, floodplain, and estuarine components of freshwater ecosystems and a range of streamflow conditions including floods, high-flow pulses, base flows, and extreme low flows. The purpose of this report is to describe current implementation of environmental flow prescriptions at these five sites and to inventory investigations that evaluate the effects of environmental flow prescriptions at four of those sites.

\footnotetext{
${ }^{1}$ U.S. Geological Survey and The Nature Conservancy, Seattle, Washington
} 
At SRP demonstration sites, environmental flow prescriptions are essentially hypotheses typically developed during expert workshops based on the best available information (Richter and others, 2006). Monitoring and evaluation of environmental flow prescriptions are important to verify the hypothesized responses, to revise prescriptions so that they are more effective and represent a more efficient use of water available for ecological objectives, and to link direct responses to prescriptions to broader outcomes for populations, communities, and ecosystems. Efforts to evaluate environmental flow prescriptions include field studies that document baseline conditions, experimental investigations of ecological responses to individual prescribed releases, and long-term ecological monitoring that represents the integrated effects of multiple prescribed releases comprising dam re-operation. Simulation models also have played a valuable role in predicting physical responses to prescribed releases and in modifying prescriptions to improve their outcomes.

\section{Demonstration Sites with Implemented Environmental Flows in the Sustainable River Project}

\section{Green River Dam, Green River, Kentucky}

The Green River (Hydrologic Unit Code, or HUC, 501100) drains 23,400 $\mathrm{km}^{2}$ in the southeastern interior plateau, valley, and hills of Kentucky (fig. 1). It is a tributary to the Ohio River that harbors diverse assemblages of native fishes (150 species according to Butler and others, 2003), and mussels (72 species as reported by Layzer and others, 2001) especially in the upper basin upstream of the Barren River at river kilometer (RKM) 241(all river kilometers in this report are approximate). The Nature Conservancy has been working to conserve biodiversity in the Green River Bioreserve, which extends from Green River Dam (RKM 492) to the confluence with the Nolin River (RKM 295) in Mammoth Caves National Park. Priority targets for conservation in the Green River include freshwater mussels and fish assemblages. Restoration of the physical hydrology of the river also has been important because of the sensitivity of the stream-cave system in Mammoth Cave National Park.

Prior to regulation, mean streamflow for the Green River at Munfordville, Kentucky, was $73.2 \mathrm{~m}^{3} / \mathrm{s}$ and median annual maximum daily streamflow was $738 \mathrm{~m}^{3} / \mathrm{s}$ (table 1 ) with a largely seasonal hydrograph (fig. 2). High flows primarily occur from December through March, although maximum monthly mean streamflow was greater than $88 \mathrm{~m}^{3} / \mathrm{s}$ in all months prior to regulation. Low flows occur in September and October.

Green River Dam near Campbellsville was constructed in 1969 and has been operated by the Corps for flood control, water supply, water quality, and recreation. Total reservoir storage, which generally is larger than operational storage, is 0.39 of pre-regulation mean streamflow (table 2). After regulation but prior to implementation of environmental flow prescriptions, mean streamflow was $81.6 \mathrm{~m}^{3} / \mathrm{s}$ and median annual maximum daily streamflow was $620 \mathrm{~m}^{3} / \mathrm{s}$ (table 1).

Environmental flows prescriptions for the Green River were developed by The Nature Conservancy and the Corps from 1999 through 2002 (table 3). The prescriptions were implemented by the Corps beginning in December 2002 and continued on a trial basis through 2005 and under the revised Green River Dam water control plan and the Green River Lake guide curve since 2006. Prescriptions include (1) delaying the initiation of reservoir drawdown from early September to November and using variable release rates to mimic natural storm events, (2) increasing the reservoir water level during flood season (winter pool elevation) and using variable release rates after storms to return reservoir to winter pool elevation, (3) extending reservoir refilling (which had 
been from mid-March to mid-April and now runs from mid-March through mid-May), and (4) increasing the maximum release rate from 204 to $230 \mathrm{~m}^{3} / \mathrm{s}$. The changes in reservoir drawdown, winter pool elevation, and refill decrease the release of cold, hypolimentic water during the autumn (during drawdown) and increase releases in spring (during refill). In addition, the duration of elevated streamflow, which is required to lower the reservoir after storms, was decreased as a result of increasing the maximum release rate and the winter pool elevation. The prescriptions were based on the general hypotheses that the river, floodplain, and cave ecosystem would benefit from streamflow patterns more similar to pre-dam conditions and from avoidance of cold water released during reservoir drawdown.

Investigations of ecological responses in the Green River to dam re-operations have used a long-term monitoring approach rather than an experimental design focused on discrete streamflow events or conditions (table 3). Investigations of fishes, mussels, other benthic invertebrates, and physical hydrology (including water quality and sediment transport) were conducted prior to the dam re-operations, providing an ecological baseline with only limited information since dam reoperation (Layzer and others, 2001; Summers, 2004; Thomas and others, 2004; Lienesch, 2008; McMurray and Schuster, 2003). Investigation of mussel reproduction and recruitment has continued (for example, Moles and Layzer, 2008). Because dam re-operation was specified in terms of reservoir pool elevation and operating policies of Green River Dam rather than streamflow components, a reservoir simulation model was developed to examine the changes in streamflow produced by dam re-operation (Thompson, 2005).

\section{Thurmond Dam, Savannah River, Georgia and South Carolina}

The Savannah River (HUC 0306) flows from the Blue Ridge Mountains (southern Appalachians) through the Piedmont to the coastal plain between Georgia and South Carolina (fig. 1). The river has a $26,400 \mathrm{~km}^{2}$ basin. It supports a productive fishery, diverse aquatic communities and floodplain forests, and brackish marshes and an estuary where it flows into the Atlantic Ocean. Floodplain forests in the southeastern United States are a significant national conservation priority for The Nature Conservancy, which has been working to protect this ecosystem along the Savannah River.

Prior to regulation, mean streamflow for the Savannah River at Augusta was $297 \mathrm{~m}^{3} / \mathrm{s}$ and median annual maximum daily streamflow was $2,547 \mathrm{~m}^{3} / \mathrm{s}$ (table 1 ). The river has a weakly seasonal hydrograph with highest streamflow from February to March (fig. 3). Low flows commonly occur in September and October; however, high flows have occurred during these months in some years. The range of inter-annual variability in monthly mean streamflow is relatively low for all months.

Thurmond Dam was constructed in 1954 and has been operated for multiple purposes including flood control, power generation, water supply, recreation, water quality, and fish and wildlife. Total reservoir storage capacity is 0.50 of pre-regulation mean streamflow (table 2). After regulation but prior to implementation of environmental flow prescriptions, mean streamflow was $264 \mathrm{~m}^{3} / \mathrm{s}$ and median annual maximum daily streamflow was $872 \mathrm{~m}^{3} / \mathrm{s}$ (table 1 ). 
Environmental flow prescriptions for the Savannah River at Augusta were developed at a workshop in April 2003 to address streamflow requirements for river, floodplain, and estuarine ecosystems based on background materials on hydrology and ecology of the Savannah River compiled by a team from the University of Georgia, Athens (Meyer and others, 2003). Scientists posed hypotheses about how each of these systems would respond to environmental flow components and recommended streamflow prescriptions that would be necessary to restore and conserve them (table 3). High-flow pulses were released from Thurmond Dam in 2004, 2005, and 2006 (fig. 3). Many of the low-flow prescriptions also have been implemented (table 3). Flood prescriptions have not been implemented because of the hazards posed by these streamflows to human uses of floodplains.

The prescriptions target a wide range of processes and conditions representing both biological and physical targets: migration, spawning, and recruitment of diadromous fish; spawning and forging habitat for resident fish; freshwater mussel recruitment; tree species composition of riparian forests, and nesting and foraging habitats for birds in riparian forests; shellfish populations and their parasites; marsh community composition; sediment and nutrient dynamics; and water quality (salinity) in the estuary.

Monitoring and evaluation in the Savanna River address the most important ecological targets: hydrologic connectivity between river and off-channel habitats, sturgeon migration and striped bass spawning, mussel recruitment, shoal spider lily distribution, tree composition of riparian forests, and fish composition in channel and floodplain habitats (Wrona and others, 2007). Monitoring of physical hydrology includes streamflow, periodic basic water-quality parameters in the river, measurements of stage on floodplains, and dissolved oxygen and salinity measurements in the estuary during high pulses. Simulation models have been developed and applied to dam reoperation, including a one-dimensional hydraulic model of the river, a reservoir-operation model for Thurmond Dam, and a two-dimensional hydraulic model of the estuary (table 3). Monitoring and evaluation of prescribed streamflows have had broad participation from academic researchers (University of Georgia, Augusta State University, and Southeast Natural Sciences Academy), The Nature Conservancy, and State and Federal agencies (Georgia Department of Natural Resources, South Carolina Department of Fish and Wildlife, and U.S. Geological Survey).

\section{Bill Williams River, Arizona}

The Bill Williams River (HUC 150302) in Arizona is a tributary to the lower Colorado River. The river drains 13,700 $\mathrm{km}^{2}$ in the Sonoran Desert, Arizona plateau, and upper Gila Mountains (fig. 1). The river and its riparian cottonwood-willow forests and mesquite bosques are important for neotropical migratory and resident birds and other desert wildlife that depend on riparian and aquatic habitats. The U.S. Fish and Wildlife Service manages the Bill Williams River National Wildlife Refuge (RKM 2 to 20) in particular to protect cottonwood-willow floodplain forests that are now rare in the lower Colorado River basin.

Prior to regulation, mean streamflow for the Bill Williams River was $2.7 \mathrm{~m}^{3} / \mathrm{s}$ and median

annual maximum daily streamflow was $87 \mathrm{~m}^{3} / \mathrm{s}$ (table 1 ). The magnitude of high flows relative to mean flows in the Bill Williams River is much greater than the other rivers in the SRP. Seasonally, high flows generally occur in February and March and in August. Low flows are common in September through December and May through July, but can occur in any month. The river has extreme inter-annual variability as indicated by the range of mean streamflow in any month of the year (fig. 4). 
Alamo Dam was constructed at RKM 62 on the Bill Williams River in 1968 and is operated by the Corps for flood control and recreation. Total reservoir storage is 21 times pre-regulation mean streamflow (table 2), but is not operated to provide inter-annual storage because of its floodcontrol purpose. After regulation, but prior to environmental flow implementation, mean streamflow was $4.1 \mathrm{~m}^{3} / \mathrm{s}$ and median annual maximum daily streamflow was $9.3 \mathrm{~m}^{3} / \mathrm{s}$ (table 1).

Environmental flow requirements for the Bill Williams River were developed at a workshop held in March 2005. Streamflow requirements were identified for riparian vegetation, aquatic organisms (native fishes, invertebrates, and reptiles and amphibians), and birds and other riparian fauna (Shafroth and Beauchamp, 2006). The requirements provided the basis for a range of flood and base flow prescriptions (table 3). The first prescribed releases were recessional flows from natural high-flow events in March 2005. Prescribed releases of small floods were made in the spring of 2006, 2007, and 2008. Dam operations in 2006-08 also have been consistent with low flow prescriptions for September to April.

The ecological goals of the high-flow prescription include re-establishment of lotic habitats that have been converted to lentic habitats by beaver dams; dispersal, germination, and recruitment of cottonwood and willow on floodplains; and increasing the occurrence of native aquatic species (fishes and invertebrates). An experimental approach to evaluation of streamflow prescriptions has been used on the Bill Williams River with monitoring of floodplain vegetation, beaver dams, fish, and invertebrates responses specifically tied to high-flow pulses (Shafroth and others, 2010; table 2). Investigations prior to prescribed releases (Shafroth and others, 2002) provide baseline information on the distribution and composition of floodplain vegetation that can be incorporated in long-term monitoring. Monitoring and evaluation has been a collaborative effort of Federal and State agencies (U.S. Fish and Wildlife Service, U.S. Geological Survey, U.S. Army Corps of Engineers, Bureau of Land Management, Bureau of Reclamation, and Arizona Department of Fish and Game), university researchers, and private contractors.

Simulation models have been applied to the Bill Williams River to investigate river hydraulics and groundwater in alluvial basins (table 3). The Corps developed a new model, the Ecosystem Functions Model (HEC-EFM), to assess a specified release (for example, a high-flow pulse prescription) in terms of an ecological requirement (for example, the rate of stage decline required by cottonwood for seedling establishment) (Hickey, 2007; Shafroth and others, 2010).

\section{Big Cypress Creek, Texas}

Big Cypress Creek is a tributary to the Red River that drains $7,100 \mathrm{~km}^{2}$ in the east-central Texas plains (HUCs 1140305, 1140306, and 1140307) (fig. 1). Big Cypress Creek flows into Caddo Lake, a globally significant wetland (Ramsar, 2009) that includes hardwood and bald cypress floodplains forests. Black Cypress Bayou and Little Cypress Creek are two other major unregulated tributaries to Big Cypress Creek. In addition to floodplain forests, Big Cypress Creek supports aquatic communities including populations of paddlefish, bluehead shiners, and freshwater mussels that been declining (Winemiller and others, 2005).

Upstream of these tributaries, mean streamflow for Big Cypress Creek near Jefferson was $19.7 \mathrm{~m}^{3} / \mathrm{s}$ and median annual maximum daily streamflow was $176 \mathrm{~m}^{3} / \mathrm{s}$ prior to regulation (table 1 ). The creek has a seasonal pattern with high flows from January through May and low flows in August and September (fig. 5). High flows can occur in any month of the year and mean streamflow in any month can vary considerably from year to year. 
Ferrells Bridge Dam was constructed in 1959 and is operated for flood control and recreation. Total reservoir storage in Lake O’ the Pines Reservoir is 3.9 times the annual streamflow (table 2). After regulation but prior to implementation of environmental flows, mean streamflow was $17.0 \mathrm{~m}^{3} / \mathrm{s}$ and median annual maximum daily streamflow was $76.5 \mathrm{~m}^{3} / \mathrm{s}$ (table 1).

Environmental flow prescriptions initially were developed for Big Cypress Creek in May 2005 for conservation of the river and flood-plain ecosystems. A team from Texas A\&M University compiled background material for the streamflow workshop (Winemiller and others, 2005). The priority targets for environmental flow prescriptions are regeneration of cypress and other riparian tree species, improved habitat for paddlefish and other fishes, connectivity of river and floodplain habitats (ox bow lakes, backwater), and sediment transport processes that maintain and create channel and off-channel habitats. Environmental flows were not prescribed specifically for Caddo Lake because Ferrells Bridge Dam only regulates about one-third (32 percent) of inflow to the lake, but seasonal variation in lake levels, which have been held relatively constant by a weir at the lake outlet, has been identified as an important factor for bald cypress regeneration and control of non-native vegetation. High-flow pulses and small floods were released in 2007 and 2008 (table 3). Dam operations in 2008 generally were consistent with low-flow prescriptions for October-June in dry years.

A number of organizations and agencies have been involved in monitoring and evaluation of Big Cypress Bayou and Caddo Lake including U.S. Geological Survey, U.S. Army Corps of Engineers, Caddo Lake Institute, U.S. Fish and Wildlife Service, and Texas Department of Parks and Wildlife. Monitoring has focused on surveys of (1) physical hydrology (stage, cross-sections) to evaluate inundation of floodplains and off-channel habitats, channel morphology and in-stream habitat to assess the effects of prescribed releases on hydraulic conditions (depth and velocity), and (2) fish and mussels to document baseline biological conditions. The Corps has been revising a one-dimensional hydraulic model with floodplain cross-sections to improve simulations of prescribed low and high streamflow in terms of connectivity of channel and off-channel habitats, and floodplain inundation.

\section{Middle Fork Willamette River, Oregon}

The Middle Fork Willamette River drains 3,470 $\mathrm{km}^{2}$ of the west slope of the Cascade Range in Oregon (fig. 1). It flows into the Willamette valley where it joins the Coast Fork Willamette River and McKenzie River to form the main stem of the Willamette River. The Middle Fork Willamette River is an important tributary of the Willamette River that supports 31 native fishes, including Oregon chubb, bull trout, steelhead, Chinook salmon, and lamprey (Gregory and others, 2007a). In places, it retains functional floodplain forests that provide habitat for diverse assemblages of birds, mammals, amphibians, and vegetation as well as off-channel habitat for aquatic species (Gregory and others, 2007a).

Prior to regulation, mean streamflow for the Middle Fork Willamette River near Dexter,

Oregon, was $101 \mathrm{~m}^{3} / \mathrm{s}$ (table 1) with a seasonal pattern of high flows from November through February, moderate flows maintained by snowmelt from March through June, and low flows in August and September (fig. 6). Inter-annual variation is greatest in November through January during the early part of the wet season. Median annual maximum daily streamflow was $854 \mathrm{~m}^{3} / \mathrm{s}$ prior to regulation, which is small relative to mean streamflow in comparison to the other rivers (table 1). 
The Corps operates three flood-control dams (Hills Creek completed in 1962, Lookout Point completed in 1953, and Fall Creek completed in 1965) and one reregulating dam (Dexter completed in 1955) in the Middle Fork Willamette River basin. Total reservoir storage of the four reservoirs is 0.33 of the pre-regulation mean streamflow of the river (table 2). After regulation but before implementation of environmental flow prescriptions, mean streamflow for the Middle Fork Willamette River was $84.6 \mathrm{~m}^{3} / \mathrm{s}$ and median annual maximum daily streamflow was $323 \mathrm{~m}^{3} / \mathrm{s}$.

Environmental flow prescriptions for the Middle Fork Willamette River were developed at a workshop in January 2007 (Gregory and others, 2007b) using background information compiled by a team from Oregon State University (Gregory and others, 2007a). The prescriptions address four components of the hydrograph for Middle Fork Willamette River: low flows, high-flow pulses, small floods, and large floods. The ecological goals include re-establishment of physical processes creating and connecting in-channel and off-channel habitats, recruitment of cottonwood on floodplains, promoting salmon migration, and mitigating thermal impacts of the dam releases. A high-flow pulse was released in 2008 (table 3). Environmental flow prescriptions for the Middle Fork Willamette River are part of a larger effort to develop and implement environmental flow prescriptions for the entire Willamette River basin (for example, Risley and others, 2010).

\section{Summary}

The Nature Conservancy has been working with U.S. Army Corps of Engineers (Corps) through the Sustainable Rivers Project (SRP) to modify operations of dams to achieve ecological objectives in addition to meeting the authorized purposes of the dams. Environmental flow prescriptions, which quantify the magnitude, duration, frequency, and seasonal timing of releases to achieve specific ecological outcomes, have been implemented at five demonstrations sites as of 2008. Those sites are located on the Green River, Kentucky; Savannah River, Georgia/South Carolina; Bill Williams River, Arizona; Big Cypress Creek, Texas; and Middle Fork Willamette River, Oregon. Ecological outcomes of those environmental flow prescriptions have been monitored and evaluated through collaborative partnerships of federal and state agencies, universities, and nongovernmental organizations. 


\section{References Cited}

Butler, R.S., Kessler, R., and Harrel, J.B., 2003, Down by the Green River: U.S. Fish and Wildlife Service Endangered Species Bulletin v. 28. no. 2, p. 20-21.

Conrads, P.A., Roehl, E.A., Daamen, R,C,, and Kitchens, W.M., 2006, Simulation of water levels and salinity in the rivers and tidal marshes in the vicinity of the Savannah National Wildlife Refuge, Coastal South Carolina and Georgia: U.S. Geological Survey Scientific Investigations Report 2006-5187, accessed October 23, 2009, at http://pubs.usgs.gov/sir/2006/5187/.

Gregory, S., Ashkenas, L., and Nygaard, C., 2007a, Summary report to assist development of ecosystem streamflow recommendations for the Coast Fork and Middle Fork of the Willamette River, Oregon, Institute for Water and Watersheds: Corvallis, Oreg., Oregon State University Final report to The Nature Conservancy and U.S. Army Corps of Engineers, 57 p. plus 26 tables, 98 figures, and 3 appendices.

Gregory, S., Ashkenas, L., and Nygaard, C., 2007b, Environmental Flow Workshop for the Middle Fork and Coast Fork of the Willamette River, Oregon: Corvallis, Oreg., Institute for Water and Watersheds, Oregon State University, Summary report to The Nature Conservancy and U.S. Army Corps of Engineers, $34 \mathrm{p}$.

Hickey, J.T., 2007, Models and software for supporting ecologically sustainable water management: Water Resources Impact v. 9, p. 10-14.

Layzer, J.B., Brady, T.R., and Cicerello, R.R., 2001, Status of the mussel fauna in the Green River between Mammoth Cave National Park and the Green River Dam: Campbellsville, Ky., U.S. Geological Survey, Tennessee Technological University, and Kentucky State Nature Preserves Commission, Final report to The Nature Conservancy, 19 p.

Lienesch, P.W., 2008, Long term fish population monitoring of the Green River and its tributaries in Mammoth Cave National Park: Bowling Green, Ky., Western Kentucky University, Final report to Mammoth Cave National Park, 23 p. plus 1 appendix.

Meyer, J., Alber, M., Duncan, W., Freeman, M. Hale, C., Jackson, R., Jennings, C., Palta, M., Richardsons, E., Sharitz, R., Sheldon, J., and Weyers,R., 2003, Summary report supporting the development of ecosystem streamflow recommendations for the Savannah River below Thurmond Dam: Athens, Ga.,, University of Georgia, Final report to the Nature Conservancy, 88 p. plus 20 tables, 36 figures, and 2 appendixes.

McMurray, P.D., and Schuster, G.A., 2003, A continuation of the bioassessment of the macroinvertebrates (excluding Unionidae) of the Green River below Green River Lake Dam with a comparison of result with the initial bioassessment of 2000: Campbellsville, Ky., Eastern Kentucky University, report to The Nature Conservancy, 30 p. plus 3 appendixes.

Moles, K.R., and Layzer, J.B., 2008, Reproductive ecology of Actinonaias ligamentina (Bivalvia: Unionidae) in a regulated river: Journal of the North American Benthological Association v. 27, p. 212-222.

Ramsar, 2009, Ramsar sites in order of addition to the Ramsar List of Wetlands of International Importance: accessed February 26, 2010, at http://www.ramsar.org/pdf/sitelist_order.pdf

Richter, B.D., A.T. Warner, J.L. Meyer, and K. Lutz, 2006, A collaborative and adaptive process for developing environmental flow recommendations: River Research and Applications, v. 22, p. 297-318.

Risley, John, Wallick, J.R., Waite, Ian, and Stonewall, Adam, 2010, Development of an environmental flow framework for the McKenzie River basin, Oregon: U.S. Geological Survey Scientific Investigations Report 2010-5016, 94 p. 
Shafroth, P. and Beauchamp, V. (eds.), 2006, Defining ecosystem flow requirements for the Bill Williams River, Arizona: U.S. Geological Survey Open-File Report 2006-1314, 135 p.

Shafroth, P.B., Stromberg, J.C., and Patten, D.T., 2002, Riparian vegetation response to altered disturbance and stress regimes: Ecological Applications v. 12, p. 107-123.

Shafroth, P.B., Wilcox, A.C., Lytle, D.A., Hickey, J.T., Andersen, D.C., Beauchamp, V.B., Hautzinger, A., McMullen,L.E., and Warner, A., 2010, Ecosystem effects of environmental flows: modeling and experimental floods in a semiarid river: Freshwater Biology v. 55, p. 68-85, doi:10.1111/j.1365-2427.2009.02271.x.

Southeast Natural Sciences Academy, no date, Savannah River at Risk Urban Corridor Study, accessed: March 4, 2010, at http://www.phinizyswamp.org/textfiles/abstract-currSRAR\%20CURR\%20urban\%20corridor\%20study.htm

Summers, R.B., 2004, Dam management strategies and their impacts on lotic macroinvertebrate secondary production in the Green River, Kentucky: phase two, establishment of year-over-year data from 2002-2003: Campbellsville, Ky., Campbellsville University, Final report to The Nature Conservancy, 16 p. plus 9 figures.

Thomas, M., Burr, B.M., Stewart, J., and Henry, D.B., 2004, Fishes of the Green River Bioreserve, Kentucky: faunal composition, community structure, and historical overview: Southern Illinois University at Carbondale and Three Rivers Environmental Assessments, Progress report to The Nature Conservancy, Campbellsville, Kentucky, 20 p.

Thompson, K., 2005, Green River Basin Reservoir Simulations: U.S. Army Corps of Engineers, San Francisco District, San Francisco California, 30 p. plus 4 appendixes.

Wiele, S.M., Hart, R.J., Darling, H.L., and Hautzinger, A.B., 2009, Sediment transport in the Bill Williams River and turbidity in Lake Havasu during and following two high releases from Alamo Dam, Arizona, in 2005 and 2006: U.S. Geological Survey Scientific Investigations Report 20095195, 22 p.

Winemiller, K.O., Chin, A., Davis, S.E., Roelke, D.L., Romero, L.M., and Wilcox, B.P., 2005, Summary report supporting the development of flow recommendations for the stretch of Big Cypress Creek below Lake O’ the Pines Dam: College Station, Tex., Texas A\&M University, Final Report .

Wrona, A, Wear, D., Ward, J., Sharitz, R. Rosenzweig, J., Richardson,J.P., Peterson, D., Leach, S., Lee, L., Jackson, C.R., Gordon, J., Freeman, M., Flite, O., Eidson, G., Davis, M., and Batzer, D., 2007, Restoring ecological flows to the lower Savannah River: a collaborative scientific approach to adaptive management: Proceedings of the 2007 Georgia Water Resources Conference, March 27-29, 2007, University of Georgia, Athens, Georgia. 


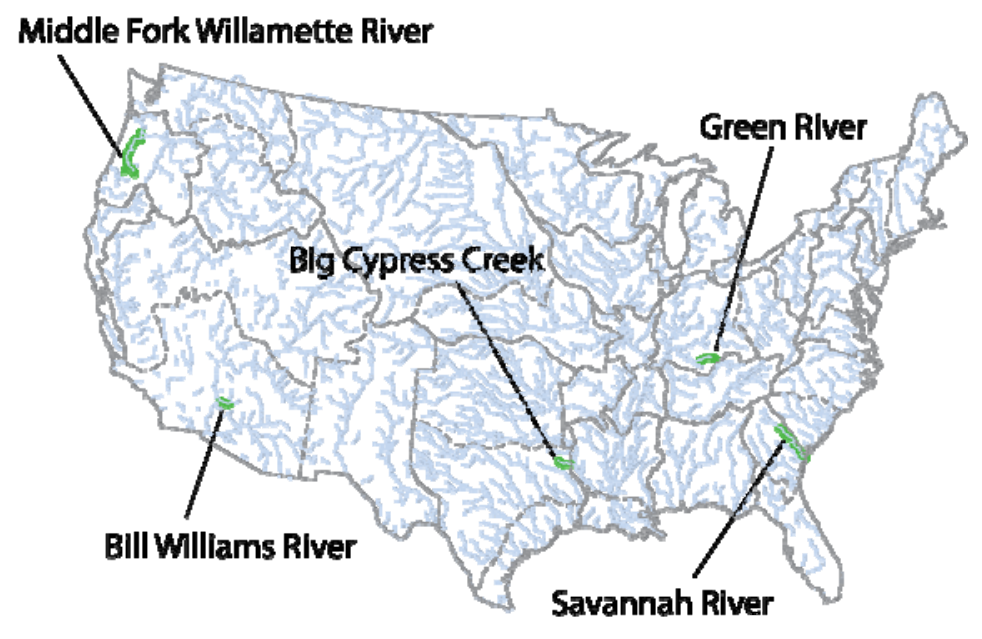

Figure 1. Map of five demonstration sites with implemented environmental flow prescriptions as part of the Sustainable Rivers Project.

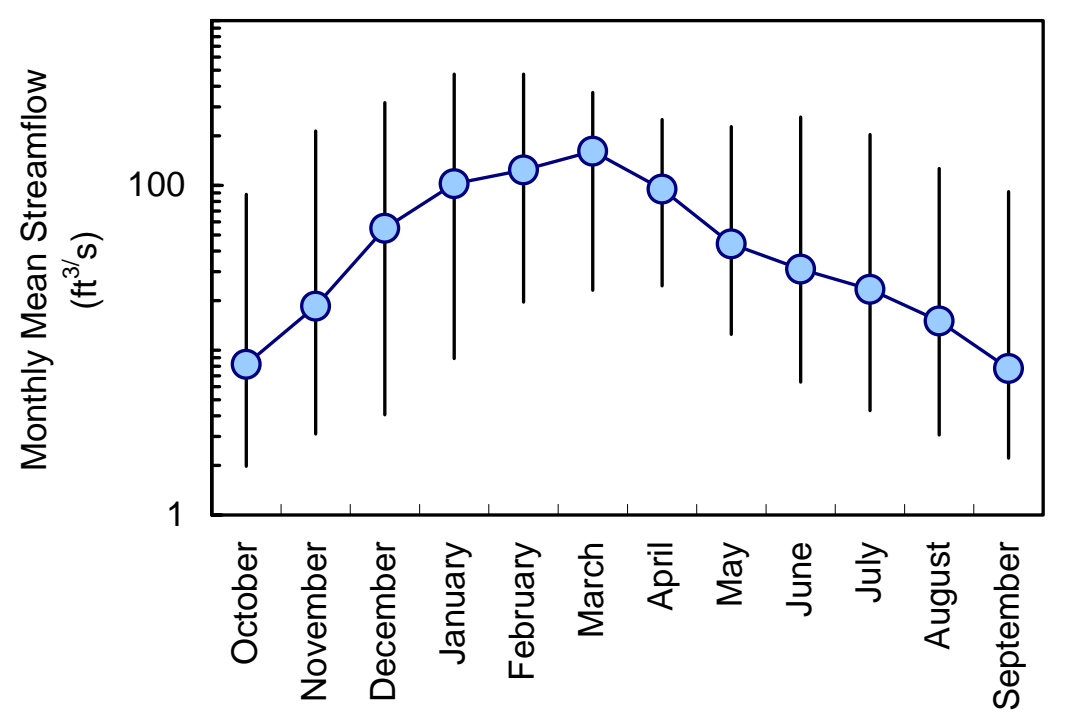

Figure 2. Median monthly mean streamflow prior to regulation (circles) for the Green River at Munfordville, Kentucky (USGS station 03308500), with minimum and maximum monthly mean streamflow (vertical lines). 


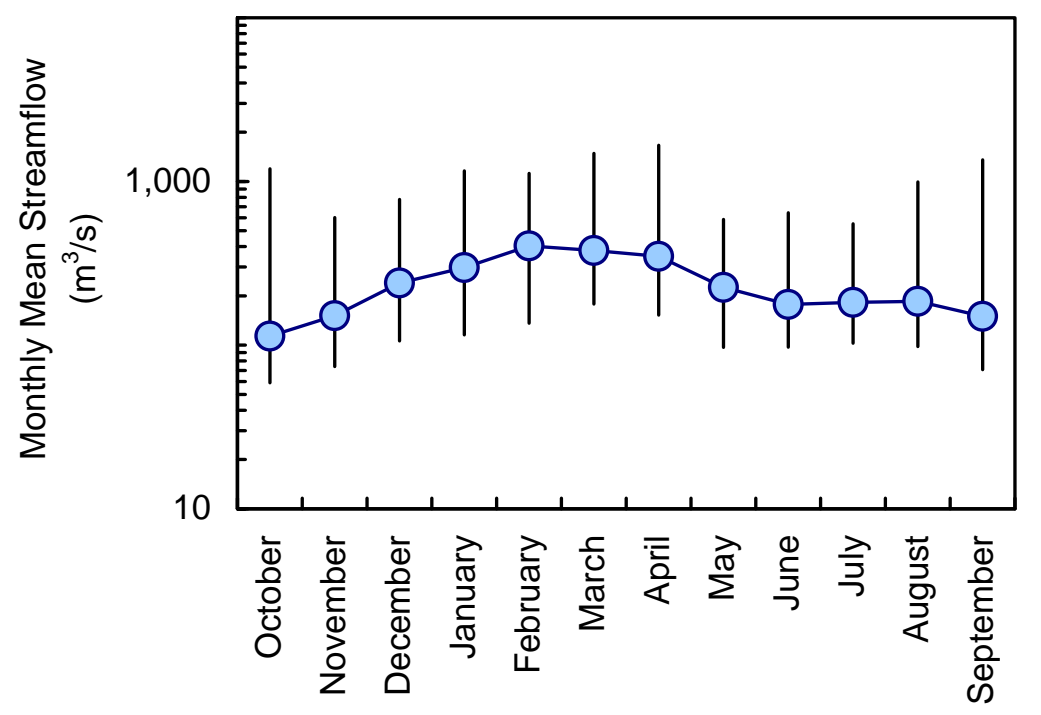

Figure 3. Median monthly mean streamflow prior to regulation (circles) for the Savannah River at Augusta, Georgia (USGS station 02197000), with minimum and maximum monthly mean streamflow (vertical lines).

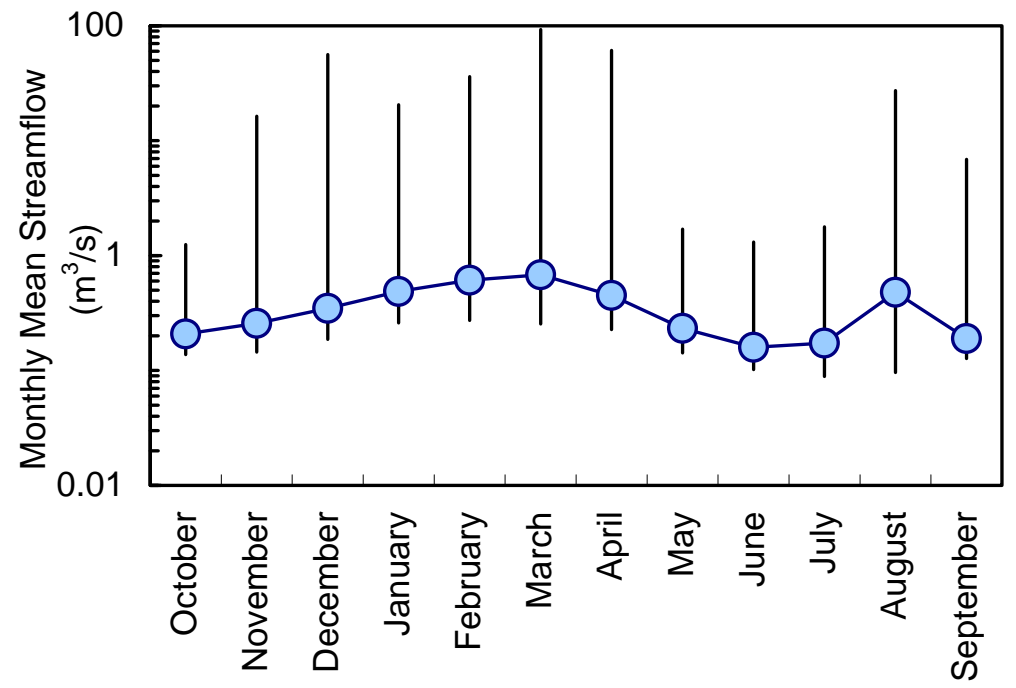

Figure 4. Median monthly mean streamflow prior to regulation (circles) for the Bill Williams River downstream of the Alamo dam site, Arizona (USGS station 09426000), with minimum and maximum monthly mean streamflow (vertical lines). 


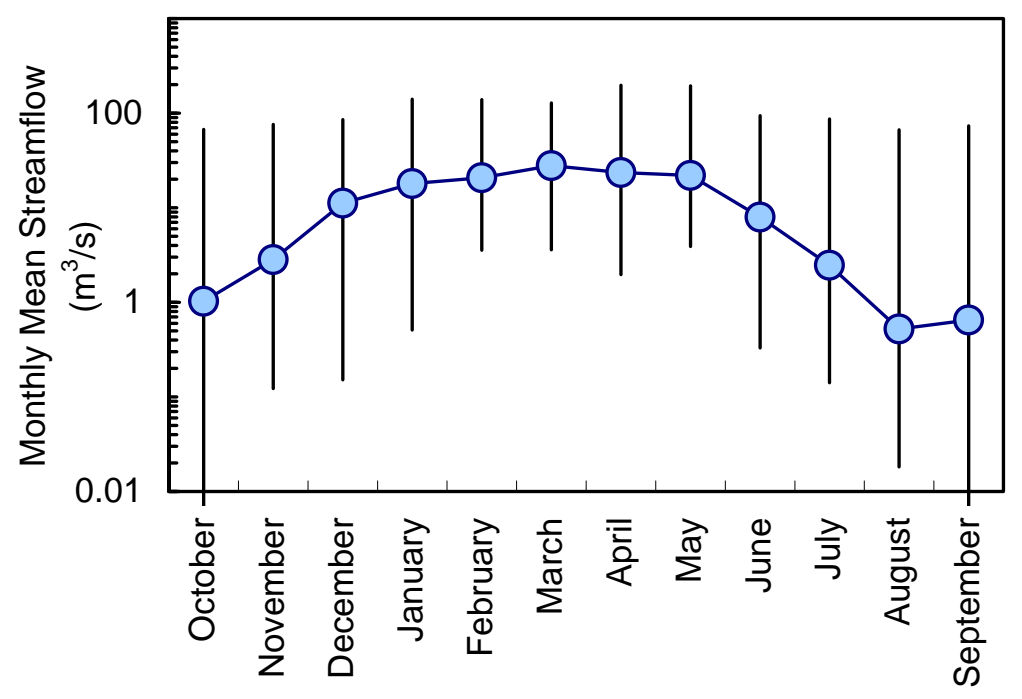

Figure 5. Median monthly mean streamflow prior to regulation (circles) for Big Cypress Creek near Jefferson, Texas (USGS station 07346000), with minimum and maximum monthly mean streamflow (vertical lines).

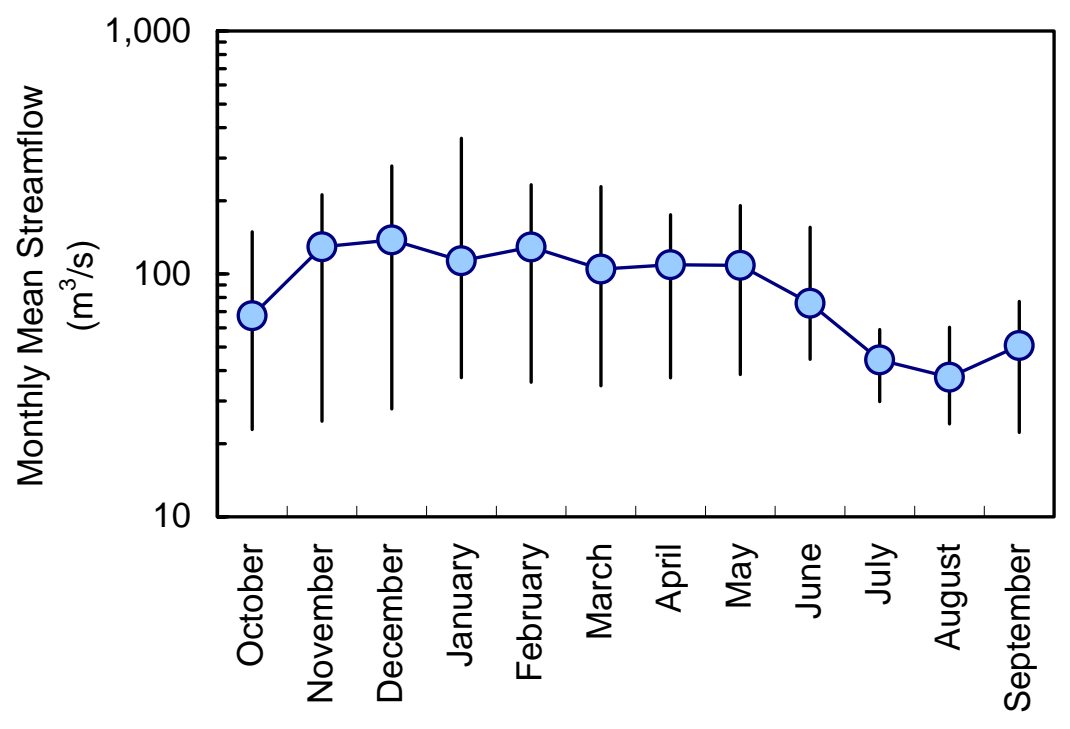

Figure 6. Median monthly mean streamflow prior to regulation (circles) for Middle Fork Willamette River near Dexter, Oregon (USGS station 14150000), with minimum and maximum monthly mean streamflow (vertical lines). 
Table 1. Streamflow information downstream of five demonstration sites in the Sustainable Rivers Project.

$\left[\mathrm{m}^{3} / \mathrm{s}\right.$, cubic meters per second]

\begin{tabular}{|c|c|c|c|c|c|c|c|c|c|}
\hline \multirow{3}{*}{ River } & \multirow[b]{2}{*}{$\begin{array}{c}\text { USGS } \\
\text { streamflow- } \\
\text { gaging station } \\
\text { downstream of } \\
\text { dam }\end{array}$} & \multicolumn{4}{|c|}{ Prior to regulation } & \multicolumn{4}{|c|}{ Post regulation, prior to environmental flow implementation } \\
\hline & & Period & $\begin{array}{c}\text { Mean } \\
\text { streamflow }\end{array}$ & $\begin{array}{l}\text { Median } \\
\text { annual } \\
\text { maximum } \\
\text { daily } \\
\text { streamflow }\end{array}$ & $\begin{array}{l}\text { Median } \\
\text { annual } \\
\text { minimum } \\
\text { daily } \\
\text { streamflow }\end{array}$ & Period & $\begin{array}{c}\text { Mean } \\
\text { streamflow }\end{array}$ & $\begin{array}{l}\text { Median } \\
\text { annual } \\
\text { maximum } \\
\text { daily } \\
\text { streamflow }\end{array}$ & $\begin{array}{l}\text { Median } \\
\text { annual } \\
\text { minimum } \\
\text { daily } \\
\text { streamflow }\end{array}$ \\
\hline & Station No. & Water years & $\mathrm{m}^{3} / \mathrm{s}$ & $\mathrm{m}^{3} / \mathrm{s}$ & $\mathrm{m}^{3} / \mathrm{s}$ & Water years & $\mathbf{m}^{3} / \mathbf{s}$ & $\mathrm{m}^{3} / \mathrm{s}$ & $\mathrm{m}^{3} / \mathrm{s}$ \\
\hline Green River, Kentucky & 03308500 & $\begin{array}{l}\text { 1916-1922, } \\
\text { 1928-1931, } \\
1938-1968\end{array}$ & 73.2 & 738 & 2.7 & 1970-2002 & 81.6 & 620 & 6.1 \\
\hline $\begin{array}{l}\text { Savannah River, Georgia } \\
\text { and South Carolina }\end{array}$ & 02197000 & 1884-1953 & 297 & 2,547 & 66.6 & 1955-2003 & 264 & 872 & 139 \\
\hline $\begin{array}{l}\text { Bill Williams River, } \\
\text { Arizona }\end{array}$ & 09426000 & $1941-1967$ & 2.7 & 87 & 0.11 & 1969-2005 & 4.1 & 9.3 & 0.11 \\
\hline Big Cypress Creek, Texas & 07346000 & 1925-1958 & 19.7 & 176 & 0.11 & 1960-2006 & 17.0 & 76.5 & 0.37 \\
\hline $\begin{array}{l}\text { Middle Fork Willamette } \\
\text { River, Oregon }\end{array}$ & 14150000 & 1947-1952 & 101 & 854 & 21.3 & 1966-2007 & 84.6 & 322.9 & 30.0 \\
\hline
\end{tabular}


Table 2. U.S .Army Corps of Engineers Dams in the Sustainable Rivers Project that have implemented environmental flow prescriptions.

[Location: Estimated from USGS topographic maps. Total reservoir storage generally is greater than operational storage because of dead storage and normal pool elevations. cm, centimeters; m, meters]

\begin{tabular}{|c|c|c|c|c|c|c|}
\hline \multirow[t]{2}{*}{ Dam } & \multirow{2}{*}{$\begin{array}{l}\text { Location } \\
\text { River } \\
\text { kilometer }\end{array}$} & \multirow{2}{*}{$\begin{array}{l}\text { Construction } \\
\text { Year completed }\end{array}$} & \multicolumn{2}{|c|}{ Total reservoir storage } & \multirow{2}{*}{$\begin{array}{c}\begin{array}{c}\text { Dam } \\
\text { height }\end{array} \\
\text { m }\end{array}$} & \multirow{2}{*}{$\begin{array}{c}\text { Initial releases } \\
\text { environmental flow } \\
\text { Water year }\end{array}$} \\
\hline & & & $\mathbf{c m}$ & $\begin{array}{l}\text { Fraction of pre- } \\
\text { regulation mean } \\
\text { streamflow }\end{array}$ & & \\
\hline Green River Lake Dam & 492 & 1969 & $8.9 \mathrm{E}+08$ & 0.39 & 44 & 2002 \\
\hline Thurmond Dam & 338 & 1954 & $4.7 \mathrm{E}+09$ & 0.50 & 61 & 2004 \\
\hline Alamo Dam & 62 & 1968 & $1.7 \mathrm{E}+09$ & 21 & 86 & 2006 \\
\hline $\begin{array}{l}\text { Lake O’ Pines-Ferrells Bridge } \\
\text { Dam }\end{array}$ & 130 & 1959 & $2.5 \mathrm{E}+09$ & 3.9 & 30 & 2007 \\
\hline $\begin{array}{l}\text { Hills Creek, Lookout Point, } \\
\text { Dexter, and Fall Creek }\end{array}$ & $\begin{array}{l}70^{1}, 32^{1} \\
27^{1}, 18^{2}\end{array}$ & $\begin{array}{l}1962,1953 \\
1955,1965\end{array}$ & $\begin{array}{l}4.4 \mathrm{E}+08,5.9 \mathrm{E}+08, \\
3.7 \mathrm{E}+07,1.5 \mathrm{E}+08\end{array}$ & 0.33 & $\begin{array}{l}104,84, \\
36,62\end{array}$ & 2008 \\
\hline
\end{tabular}

${ }^{1}$ River kilometers along the Middle Fork Willamette River starting from 0 at Willamette River kilometer 370.

${ }^{2}$ Location is for the confluence of Fall Creek with Middle Fork Willamette River, Fall Creek dam is 7 km upstream of confluence on Fall Creek. 
Table 3. Environmental flow prescriptions at five demonstration sites in the Sustainable Rivers Project.

[Implementation of environmental flow prescriptions was assessed by comparing prescriptions to downstream streamflow records. In some cases,

implementation may have been incidental to normal dam operations or a result of downstream tributary inflow rather than a deliberate management action]

\begin{tabular}{|c|c|c|c|}
\hline $\begin{array}{l}\text { Streamflow } \\
\text { component }\end{array}$ & Prescription & $\begin{array}{l}\text { Water years } \\
\text { implemented }\end{array}$ & Hypothesized ecological responses \\
\hline \multicolumn{4}{|l|}{ Green River } \\
\hline Small floods & $\begin{array}{l}230 \mathrm{~m}^{3} / \mathrm{s} \text { (increased from } 200 \mathrm{~m}^{3} / \mathrm{s} \text { ), November to } \\
\text { March, based on inflows }\end{array}$ & 2002-2008 & $\begin{array}{l}\text { Reduced duration of elevated streamflow required to return } \\
\text { reservoir to flood pool level after storms }\end{array}$ \\
\hline High-flow pulses & $\begin{array}{l}\text { Use pulsed releases for reservoir drawdown up to } \\
\text { two-thirds bankfull streamflow beginning in } \\
\text { November }\end{array}$ & $2002-2008$ & $\begin{array}{l}\text { Less impact than long duration of consistently high streamflow } \\
\text { for drawdown }\end{array}$ \\
\hline $\begin{array}{l}\text { High flow pulses } \\
\text { and wet season base } \\
\text { flow }\end{array}$ & $\begin{array}{l}\text { Extend refill period to April through May matching } \\
\text { inflows to the extent possible }\end{array}$ & $2002-2008$ & Less reduction in streamflow during spring refill \\
\hline Base flow & $\begin{array}{l}\text { Equal to reservoir inflow, September through } \\
\text { October }\end{array}$ & 2002-2008 & $\begin{array}{l}\text { Avoiding reservoir drawdown during September and October will } \\
\text { reduce cold water releases }\end{array}$ \\
\hline \multicolumn{4}{|l|}{ Savannah River } \\
\hline \multirow[t]{8}{*}{ Floods } & \multirow{8}{*}{$\begin{array}{l}1,400-2,000 \mathrm{~m}^{3} / \mathrm{s} \text { in January through April, } 1 \text { flood } \\
\text { every } 3 \text { years in wet or average years lasting for } 2 \\
\text { weeks }\end{array}$} & \multirow[t]{8}{*}{$\begin{array}{l}\text { Not } \\
\text { implemented }\end{array}$} & $\begin{array}{l}\text { Maintain floodplain and channel habitats including wetlands, } \\
\text { oxbows, and sloughs }\end{array}$ \\
\hline & & & Provide access for fish to floodplain \\
\hline & & & Enhance nutrient cycling \\
\hline & & & Disperse tree seeds \\
\hline & & & Control invasive species \\
\hline & & & Increase fisheries production in estuary \\
\hline & & & Transport sediment and nutrients to estuary \\
\hline & & & Improve bird habitat and forage \\
\hline \multirow[t]{11}{*}{ High flow pulses } & \multirow{11}{*}{$\begin{array}{l}570-1,100 \mathrm{~m}^{3} / \mathrm{s} \text { in January through April, five pulses } \\
\text { in wet years - } 2 \text { pulses lasting } 2 \text { weeks in March and } \\
\text { April, three pulses lasting } 2 \text { days; four pulses (one } \\
\text { pulse per month) in average years lasting } 2-3 \text { days. }\end{array}$} & \multirow[t]{11}{*}{$2006^{1}$} & $\begin{array}{l}\text { Anadromous fish passage at New Savannah Bluff Lock and Dam } \\
\text { (NSBLD) and spawning }\end{array}$ \\
\hline & & & Morone egg suspension \\
\hline & & & Reduce predation on birds \\
\hline & & & Disperse tree seeds on floodplain \\
\hline & & & Transport fish larvae \\
\hline & & & Recruit large woody debris to channel \\
\hline & & & Provide access for fish to floodplain \\
\hline & & & Improve bird habitat in estuary \\
\hline & & & Transport nutrients to estuary \\
\hline & & & Disperse seeds in estuary \\
\hline & & & Control oyster/blue crab parasites in estuary \\
\hline
\end{tabular}


Table 3. Environmental flow prescriptions at five demonstration sites in the Sustainable Rivers Project—Continued.

\begin{tabular}{|c|c|c|c|}
\hline $\begin{array}{l}\text { Streamflow } \\
\text { component }\end{array}$ & Prescription & $\begin{array}{l}\text { Water years } \\
\text { implemented }\end{array}$ & Hypothesized ecological responses \\
\hline \multicolumn{4}{|c|}{ Savannah River-Continued } \\
\hline \multirow[t]{4}{*}{$\begin{array}{l}\text { High flow pulses- } \\
\text { Continued }\end{array}$} & $\begin{array}{l}450-510 \mathrm{~m}^{3} / \mathrm{s} \text {, early March and early April, two } \\
\text { pulses in dry years lasting } 3 \text { days }\end{array}$ & $2004-2005^{1}$ & $\begin{array}{l}\text { Anadromous fish passage and spawning: herring passage at } \\
\text { NSBLD and morone egg suspension }\end{array}$ \\
\hline & $\begin{array}{l}450-510 \mathrm{~m}^{3} / \mathrm{s} \text {, early April, one pulse after } 3 \\
\text { consecutive dry years lasting } 2 \text { weeks }\end{array}$ & $2004-2005^{1}$ & Striped bass spawning \\
\hline & $\begin{array}{l}230-340 \mathrm{~m}^{3} / \mathrm{s} \text {, May-October, } 2-3 \text { days per month in } \\
\text { average years, no more than once every } 10 \text { days }\end{array}$ & 2006 & Exchange water with off-channel habitats (oxbows) \\
\hline & $\begin{array}{l}<370 \mathrm{~m}^{3} / \mathrm{s} \text {, January-July, } 3 \text { consecutive dry years } \\
\text { after riparian seed dispersal }\end{array}$ & $2008^{2}$ & Floodplain tree recruitment \\
\hline \multirow[t]{12}{*}{ Low flows } & $\begin{array}{l}170-280 \mathrm{~m}^{3} / \mathrm{s} \text {, January-May, wet years } \\
170-240 \mathrm{~m}^{3} / \mathrm{s} \text {, January-May, average years }\end{array}$ & $\begin{array}{l}\text { Not implemented } \\
2005^{3}\end{array}$ & $\begin{array}{l}\text { Shad, striped bass, robust redhorse spawning and habitat } \\
\text { Shad, striped bass, robust redhorse spawning and habitat }\end{array}$ \\
\hline & 110-170 m³/s, January-May, dry years & 2006-2007 & Shad, striped bass, robust redhorse spawning and habitat \\
\hline & 110-140 m³/s, June-December, wet years & 2005-2006 & Resident fish habitat; juvenile out-migration \\
\hline & 110-140 m³/s, October-December, wet years & 2005-2006 & Sturgeon spawning \\
\hline & 110 m³/s, June-December, average years & 2005-2006 & Resident fish habitat; juvenile out-migration \\
\hline & $>76 \mathrm{~m}^{3} / \mathrm{s}$, November and December, dry years & $2005-2008$ & Sturgeon outmigration, reduce deer predation on spider lily \\
\hline & > 76 m³/s, May-July, average and dry years & $2005-2008$ & Reduce deer predation on spider lily \\
\hline & $\begin{array}{l}>57 \mathrm{~m}^{3} / \mathrm{s} \text {, July-October, dry years } \\
>230 \mathrm{~m}^{3} / \mathrm{s} \text {. March-Mav, wet vears }\end{array}$ & $\begin{array}{l}\text { 2005-2008 } \\
\text { Not implemented }\end{array}$ & $\begin{array}{l}\text { Reduce deer predation on spider lily } \\
\text { Transport fish larvae for pelagic spawners }\end{array}$ \\
\hline & $<140 \mathrm{~m}^{3} / \mathrm{s}$, April-October, average years & 2008 & $\begin{array}{l}\text { Create shallow water habitat for fish } \\
\text { Drain floodplain }\end{array}$ \\
\hline & $\begin{array}{l}85 \mathrm{~m}^{3} / \mathrm{s} \text {, April-October for } 3 \text { consecutive dry years } \\
\text { In estuary }\end{array}$ & Not implemented & Floodplain tree recruitment \\
\hline & $\begin{array}{l}\text { Monthly mean streamflow of } 250-380 \mathrm{~m}^{3} / \mathrm{s} \text { and } \\
\text { instantaneous minimum of } 170 \mathrm{~m}^{3} / \mathrm{s} \text { in wet years; } \\
\text { high end of range for January-May, low end of } \\
\text { range for June-December, wet years }\end{array}$ & Not implemented & $\begin{array}{l}\text { Disperse seeds across marsh in estuary } \\
\text { Enhance nutrient cycling in estuary } \\
\text { Enhance invertebrate production in estuary } \\
\text { Maintain salinity gradient and fish distributions }\end{array}$ \\
\hline & $\begin{array}{l}\text { Monthly mean streamflows of } 230-340 \mathrm{~m}^{3} / \mathrm{s} \text { and } \\
\text { instantaneous minimum of } 170 \mathrm{~m}^{3} / \mathrm{s} \text { in average } \\
\text { years; monthly mean streamflows of } 170-230 \mathrm{~m}^{3} / \mathrm{s}\end{array}$ & 2006-2008 & $\begin{array}{l}\text { Maintain tidal marsh } \\
\text { Maintain salinity gradient for fish access to marsh }\end{array}$ \\
\hline
\end{tabular}


Table 3. Environmental flow prescriptions at five demonstration sites in the Sustainable Rivers Project—Continued.

\begin{tabular}{|c|c|c|c|}
\hline $\begin{array}{l}\text { Streamflow } \\
\text { component }\end{array}$ & Prescription & $\begin{array}{l}\text { Water years } \\
\text { implemented }\end{array}$ & Hypothesized ecological responses \\
\hline \multicolumn{4}{|l|}{ Bill Williams River } \\
\hline Large floods & $\begin{array}{l}>850 \mathrm{~m}^{3} / \mathrm{s} \text {, mid-September-November, short } \\
\text { duration events, and mid-November- April, one } \\
\text { event every } 25 \text { years lasting for } 2 \text { days in early } \\
\text { autumn or for } 3 \text { to } 6 \text { days in late } \\
\text { autumn/winter/spring }\end{array}$ & Not implemented & $\begin{array}{l}\text { Open areas for cottonwood and willow recruitment } \\
\text { Remove nonnative fishes and beaver dams } \\
\text { Create off-channel habitat } \\
\text { Re-set distribution of woody vegetation }\end{array}$ \\
\hline Moderate floods & $\begin{array}{l}280-850 \mathrm{~m}^{3} / \mathrm{s} \text {, mid-March-April, one pulse every } 5 \\
\text { to } 10 \text { years lasting } 2 \text { days with } 2.5 \mathrm{~cm} / \mathrm{d} \text { recession } \\
\text { rate, no floods for } 2 \text { years to allow recruitment of } \\
\text { wood vegetation }\end{array}$ & Not implemented & $\begin{array}{l}\text { Cottonwood and willow recruitment, suppress tamarisk } \\
\text { Scour channel } \\
\text { Remove nonnative fishes and beaver dams }\end{array}$ \\
\hline \multirow[t]{4}{*}{ Small floods } & $\begin{array}{l}130-140 \mathrm{~m}^{3} / \mathrm{s} \text {, February, one pulse every } 5 \text { years } \\
\text { lasting for } 1 \text { day with } 1 \text { week long recession }\end{array}$ & $2006^{4}$ & $\begin{array}{l}\text { Remove beaver dams } \\
\text { Flush riffles and off-channel pools }\end{array}$ \\
\hline & $\begin{array}{l}28-140 \mathrm{~m}^{3} / \mathrm{s} \text {, mid-July- mid-August and February, } \\
\text { one small pulse every } 3 \text { years; one large pulse every } \\
5 \text { years }\end{array}$ & $2007-2008^{4}$ & $\begin{array}{l}\text { Promote herbaceous growth } \\
\text { Avoid frequent disturbance of toad larve, ground snake eggs }\end{array}$ \\
\hline & $\begin{array}{l}28-56 \mathrm{~m}^{3} / \mathrm{s} \text {, mid-July-mid-August, one pulse every } \\
3 \text { years lasting less than } 1 \text { day }\end{array}$ & Not implemented & Decompose litter \\
\hline & $\begin{array}{l}\text { 3-14 } \mathrm{m}^{3} / \mathrm{s} \text {, mid-July- mid-August and February, one } \\
\text { pulse lasting less than } 1 \text { day every } 2 \text { years }\end{array}$ & Not implemented & Promote herbaceous growth \\
\hline Base flows & $\begin{array}{l}\text { 6-12 m³/s, late February-early April, month-long } \\
\text { duration every year during late February-early April }\end{array}$ & Not implemented & Native fish spawning \\
\hline Low flows & 0.6-1.4 m³/s, September-April & 2006-2008 & $\begin{array}{l}\text { Maintain aquatic habitat } \\
\text { Maintain riparian vegetation }\end{array}$ \\
\hline Extreme low flows & $\begin{array}{l}0.6 \mathrm{~m}^{3} / \mathrm{s} \text {, May-September, for less than } 2 \text { months in } \\
\text { dry years (frequency to be determined) }\end{array}$ & Not implemented & Fragment aquatic habitat for native species \\
\hline
\end{tabular}


Table 3. Environmental flow prescriptions at five demonstration sites in the Sustainable Rivers Project—Continued.

\begin{tabular}{|c|c|c|c|}
\hline $\begin{array}{l}\text { Streamflow } \\
\text { component }\end{array}$ & Prescription & $\begin{array}{l}\text { Water years } \\
\text { implemented }\end{array}$ & Hypothesized ecological responses \\
\hline \multicolumn{4}{|c|}{ Big Cypress Creek - Caddo Lake } \\
\hline Large floods & $570 \mathrm{~m}^{3} / \mathrm{s}$, one flood every 10 years, January-June & Not implemented & Create channel habitat \\
\hline \multirow[t]{3}{*}{ Small floods } & $\begin{array}{l}85-280 \mathrm{~m}^{3} / \mathrm{s} \text {, one flood every } 3 \text { to } 5 \text { years, January- } \\
\text { June }\end{array}$ & $2008^{5}$ & Maintain aquatic habitats(oxbows, backwaters) in floodplain \\
\hline & & & Disperse riparian seeds \\
\hline & & & $\begin{array}{l}\text { Remove vegetation along channel and suppress upland } \\
\text { species }\end{array}$ \\
\hline \multirow[t]{2}{*}{ High flow pulses } & $71 \mathrm{~m}^{3} / \mathrm{s}$, one pulse every 2 years, January-May & $2007-2008^{4}$ & Maintain aquatic habitats and connectivity of floodplain \\
\hline & $\begin{array}{l}42 \mathrm{~m}^{3} / \mathrm{s} \text {, three to five pulses lasting } 2 \text { to } 3 \text { days every } \\
\text { year, January-June }\end{array}$ & $2007^{5}$ & Sediment transport, oxbow connectivity, paddlefish spawning \\
\hline \multirow[t]{3}{*}{ Low flows } & $\begin{array}{l}2.7-15 \mathrm{~m}^{3} / \mathrm{s} \text {, November-June and } 1.1-2 \mathrm{~m}^{3} / \mathrm{s} \text {, July- } \\
\text { October; wet years }\end{array}$ & Not implemented & Maintain biodiversity and connectivity of aquatic habitats \\
\hline & $\begin{array}{l}2.2-11 \mathrm{~m}^{3} / \mathrm{s} \text {, November-June and } 1.0-1.1 \mathrm{~m}^{3} / \mathrm{s} \text {, } \\
\text { July-October in average years }\end{array}$ & Not implemented & Promote benthic drift and dispersal, fish spawning \\
\hline & $1.1-6.2 \mathrm{~m}^{3} / \mathrm{s}$, October-June in dry years & $2008^{6}$ & Maintain fish habitat and spawning \\
\hline Extreme low flows & $0.2-0.4 \mathrm{~m}^{3} / \mathrm{s}$, July-September in dry years & Not implemented & Maintain aquatic diversity \\
\hline
\end{tabular}


Table 3. Environmental flow prescriptions at five demonstration sites in the Sustainable Rivers Project—Continued.

\begin{tabular}{|c|c|c|c|}
\hline $\begin{array}{l}\text { Streamflow } \\
\text { component }\end{array}$ & Prescription & $\begin{array}{l}\text { Water years } \\
\text { implemented }\end{array}$ & Hypothesized ecological responses \\
\hline \multicolumn{4}{|c|}{ Middle Fork Willamette River } \\
\hline Large floods & $\begin{array}{l}\text { 1,130-2,260 } \mathrm{m}^{3} / \mathrm{s} \text {, mid-November-mid-March, } \\
\text { linked to storms, not recommended in final set of } \\
\text { prescriptions }\end{array}$ & Not implemented & Create new floodplain surfaces and channel \\
\hline Small floods & $\begin{array}{l}710-1,130 \mathrm{~m}^{3} / \mathrm{s} \text {, mid-November-mid-March, linked } \\
\text { to storms, not recommended in final set of } \\
\text { prescriptions }\end{array}$ & Not implemented & $\begin{array}{l}\text { Transport sediment to create channel forms (pools and riffles) } \\
\text { and floodplain surfaces (bar development) }\end{array}$ \\
\hline \multirow[t]{8}{*}{ High flow pulses } & $\begin{array}{l}42-84 \mathrm{~m}^{3} / \mathrm{s} \text {, October-mid-November, linked to } \\
\text { storms, one to four events lasting less than } 5 \text { days }\end{array}$ & Not implemented & $\begin{array}{l}\text { Promote chinook salmon migration for spawning (must avoid } \\
\text { rapid thermal changes from the release of warm reservoir } \\
\text { water) }\end{array}$ \\
\hline & $\begin{array}{l}540-710 \mathrm{~m}^{3} / \mathrm{s} \text {, mid-November-mid-March, linked to } \\
\text { storms, one to five events, duration comparable to } \\
\text { unregulated floods }\end{array}$ & Not implemented & Promote downstream migration of juvenile salmon \\
\hline & & & Create lateral aquatic habitats on floodplain margin \\
\hline & & & $\begin{array}{l}\text { Transport sediment to create channel forms (pools and riffles) } \\
\text { and floodplain surfaces (bar development) }\end{array}$ \\
\hline & $\begin{array}{l}110-420 \mathrm{~m}^{3} / \mathrm{s} \text {, March-June, linked to storms, one to } \\
\text { five events, duration comparable to unregulated } \\
\text { floods }\end{array}$ & $2008^{7}$ & Promote downstream migration of juvenile salmon \\
\hline & & & Create lateral aquatic habitats on floodplain margin \\
\hline & & & Recruit cottonwood \\
\hline & & & $\begin{array}{l}\text { Allow aquatic species to migrate from lateral refugia (over- } \\
\text { winter habitats) to main channel (summer habitats) }\end{array}$ \\
\hline Base flows & $\begin{array}{l}28-57 \mathrm{~m}^{3} / \mathrm{s} \text {, June-September, decreasing over the } \\
\text { course of the summer }\end{array}$ & Not implemented & $\begin{array}{l}\text { Provide river margin habitats for aquatic species, riparian } \\
\text { seedling, and nesting shorebirds without seasonally increasing } \\
\text { depth or inundation }\end{array}$ \\
\hline Low flows & $<42 \mathrm{~m}^{3} / \mathrm{s}$ in September for less than 5 days & Not implemented & $\begin{array}{l}\text { Avoid rapid thermal changes from the release of warm } \\
\text { reservoir water resulting from reservoir drawdown for flood } \\
\text { season, promote fish passage/migration }\end{array}$ \\
\hline \multicolumn{4}{|c|}{${ }^{1}$ High-flow pulses in the Savannah River, were released on March 15-19, 2004, February 22 -March 10, 2005, March 16-21, 2005, and March 20-25, 2006 } \\
\hline \multicolumn{4}{|c|}{${ }^{3}$ Daily streamflow in the Savannah River during 2005 was occasionally less than the low-flow prescription. } \\
\hline \multicolumn{4}{|c|}{${ }^{4}$ High-flow pulses in the Bill Williams River were released on March 12-April 8, 2006; April 9-11, 2007; March 31-April 1, 2008.} \\
\hline \multicolumn{4}{|c|}{$\begin{array}{l}{ }^{5} \text { High-flow pulses in Big Cypress Creek were released on January 20-February, 9, 2007; June 28-July 11, 2007; and July 11-August 14, 2007; five pulses/small } \\
\text { floods were released in 2008. }\end{array}$} \\
\hline \multicolumn{4}{|c|}{${ }^{6}$ Lows flow in Big Cypress Creek during September 2008 were lower $\left(0.9 \mathrm{~m}^{3} / \mathrm{s}\right)$ than the prescription. } \\
\hline
\end{tabular}


Table 4. Investigations that support monitoring and evaluation of environmental flow prescriptions at demonstrations sites of the Sustainable Rivers Project.

[Under status, "initiated" refers to limited term investigations that typically focus on baseline conditions or effects of specific prescribed releases; "on-going" refers to monitoring activities that are not targeting the effects of specific releases]

\begin{tabular}{|c|c|c|}
\hline Topic & Lead agency/organization & Status \\
\hline \multicolumn{3}{|l|}{ Green River } \\
\hline Mussel inventory & $\begin{array}{l}\text { United States Geological Survey } \\
\text { (USGS)//Tennessee Technological } \\
\text { University (TTU); Kentucky State Nature } \\
\text { Preserves Commission }\end{array}$ & Completed $^{1}$ \\
\hline Macroinvertebrate production & Campbellsville University & Completed $^{2}$ \\
\hline Modeling - Unimpaired streamflow, RESIM, IHA & $\begin{array}{l}\text { United States Army Corps of Engineers } \\
\text { (USACE) San Francisco District }\end{array}$ & Completed $^{3}$ \\
\hline Fish Community Studies & Southern Illinois University at Carbondale & Completed $^{4}$ \\
\hline Macroinvertebrate bioassessment & Eastern Kentucky University & Completed $^{5}$ \\
\hline Fish monitoring & Western Kentucky University & Completed $^{6}$ \\
\hline Mussels recruitment and high streamflow duration & USGS/TTU & On-going $^{7}$ \\
\hline Mussel monitoring & $\begin{array}{l}\text { Kentucky Department of Fish and Wildlife } \\
\text { Resources }\end{array}$ & On-going \\
\hline Spotted darter surveys & Campbellsville University & Initiated \\
\hline $\begin{array}{l}\text { Effects of reservoir drawdown and streamflow in } \\
\text { Mammoth Cave }\end{array}$ & National Park Service & Initiated \\
\hline Fish community and streamflow & Southern Illinois University at Carbondale & \\
\hline \multicolumn{3}{|l|}{ Savannah River } \\
\hline Sturgeon migration & $\begin{array}{l}\text { The Nature Conservancy (TNC), Savannah } \\
\text { River Program }\end{array}$ & Completed $^{8}$ \\
\hline Floodplain hydrology & TNC Georgia Field Office & Initiated $^{8}$ \\
\hline Floodplain vegetation & $\begin{array}{l}\text { University of Georgia, Augusta (UGA) } \\
\text { /Savannah River Ecology Laboratory }\end{array}$ & Initiated ${ }^{8}$ \\
\hline Floodplain topography & TNC Georgia Field Office & Initiated ${ }^{8}$ \\
\hline Transects - invertebrates & UGA & Initiated $^{8}$ \\
\hline Transects - fish & UGA & Initiated $^{8}$ \\
\hline Spider Lily & Augusta State University & Initiated $^{8}$ \\
\hline RESSIM & USACE Savannah District & Completed $^{8}$ \\
\hline Hydrodynamic model of estuary & $\begin{array}{l}\text { USGS South Carolina Water Science } \\
\text { Center }\end{array}$ & Completed $^{9}$ \\
\hline Mussels recruitment & $\begin{array}{l}\text { United States Fish and Wildlife Service } \\
\text { (USFWS) }\end{array}$ & On-going $^{10}$ \\
\hline CE-WQUAL-2E & Southeastern Natural Sciences Academy & Initiated $^{11}$ \\
\hline Water quality monitoring & Southeastern Natural Sciences Academy & Initiated $^{8}$ \\
\hline \multicolumn{3}{|l|}{ Bill Williams River } \\
\hline $\begin{array}{l}\text { Native riparian forest seedling establishment - } \\
\text { longitudinal profile survey, permanent plots, and } \\
\text { comparison to tamarisk }\end{array}$ & $\begin{array}{l}\text { USGS Mid-continental Ecological Science } \\
\text { Center }\end{array}$ & Completed $^{12}$ \\
\hline Beaver dam inventory & $\begin{array}{l}\text { USGS Mid-continental Ecological Science } \\
\text { Center }\end{array}$ & Completed $^{12}$ \\
\hline Ecosystem-streamflow model & USACE Hydrologic Engineering Center & Completed $^{12}$ \\
\hline $\begin{array}{l}\text { Planet Ranch soil characteristics for potential } \\
\text { cottonwood recruitment }\end{array}$ & USFWS Southwest Region & Completed $^{13}$ \\
\hline $\begin{array}{l}\text { Sediment Transport and Turbidity in Lake Havasu } \\
\text { following High Releases from Alamo Dam }\end{array}$ & $\begin{array}{l}\text { USGS Arizonia Water Science Center and } \\
\text { USFWS Southwest Region }\end{array}$ & Completed $^{14}$ \\
\hline Macroinvertebrate assemblage composition & Oregon State University & Iniitiated $^{12}$ \\
\hline Vegetation - herbaceous plant diversity & $\begin{array}{l}\text { USGS Mid-continental Ecological Science } \\
\text { Center }\end{array}$ & Initiated $^{12}$ \\
\hline
\end{tabular}


Table 4. Investigations that support monitoring and evaluation of environmental flow prescriptions at demonstrations sites of the Sustainable Rivers Project.-Continued

\begin{tabular}{|c|c|c|}
\hline Topic & Lead agency/organization & Status \\
\hline Riparian forest inventory & $\begin{array}{l}\text { USGS Mid-continental Ecological Science } \\
\text { Center, University of Nevada Reno }\end{array}$ & Initiated $^{13}$ \\
\hline Native fish occurrence & University of Washington & Initiated $^{15}$ \\
\hline Sediment transport model & $\begin{array}{l}\text { USGS Sediment Transport and } \\
\text { Geomorphology Laboratory, University of } \\
\text { Montana }\end{array}$ & Initiated $^{12}$ \\
\hline Flood Recharge Processes & University of Arizona (UA) & initiated $^{13}$ \\
\hline Groundwater model & USFWS & Completed $^{13}$ \\
\hline Construction of hydraulic model (HEC-RAS) & USACE & Initiated $^{13}$ \\
\hline LiDAR topographic data & Tetra Tech & Completed $^{12}$ \\
\hline Seismic cross-sections & USFWS Southwest Region & Completed $^{13}$ \\
\hline Reservoir operations model (RESSIM) & USACE LA District & On-going ${ }^{13}$ \\
\hline Groundwater monitoring & USFWS Southwest Region & On-going $^{13}$ \\
\hline $\begin{array}{l}\text { SW miscellaneous measurements between Alamo } \\
\text { and Colorado River }\end{array}$ & USFWS Southwest Region & On-going $^{13}$ \\
\hline $\begin{array}{l}\text { Quantifying Potential Southwestern Willow } \\
\text { Flycatcher Habitat between Alamo Dam and Bill } \\
\text { Williams River National Wildlife Refuge }\end{array}$ & Arizona Game and Fish Department & Completed $^{13}$ \\
\hline \multicolumn{3}{|l|}{ Big Cypress Creek } \\
\hline Monitoring river stage & USGS Texas Water Science Center & Completed $^{16}$ \\
\hline Fish survey & USGS Texas Water Science Center & Completed $^{16}$ \\
\hline Stream habitat survey & USGS Texas Water Science Center & Completed $^{16}$ \\
\hline Mussel survey & USGS Texas Water Science Center & Completed $^{16}$ \\
\hline $\begin{array}{l}\text { Area of inundation and related maps for evaluation of } \\
\text { over-bank prescriptions }\end{array}$ & USGS Texas Water Science Center & Completed $^{16}$ \\
\hline $\begin{array}{l}\text { In-channel features related to high-pulse and low- } \\
\text { streamflow prescriptions }\end{array}$ & USGS Texas Water Science Center & Completed $^{16}$ \\
\hline Topographic survey of extended cross sections & USACE Fort Worth District & Completed $^{16}$ \\
\hline Hydraulic model (HEC-RAS) & USACE Fort Worth District & Initiated $^{16}$ \\
\hline Hydrologic connectivity and sediment transport & USGS Texas Water Science Center & Planning ${ }^{16}$ \\
\hline Topographic survey of floodplain & USGS Texas Water Science Center & Planning $^{16}$ \\
\hline
\end{tabular}

${ }^{1}$ Layzer and others (2001).

${ }^{2}$ Summers (2004).

${ }^{3}$ Thompson (2005).

${ }^{4}$ Thomas and others (2004).

${ }^{5}$ McMurray and Schuster (2003).

${ }^{6}$ Lienesch (2008).

7 Moles and Layzer (2008)

${ }^{8}$ Wrona and others (2007).

${ }^{9}$ Conrads and others (2006).

${ }^{10}$ A.D. Wrona, written commun., February 15, 2008

${ }^{11}$ Southeast Natural Sciences Academy (no date)

${ }^{12}$ Shafroth and others (2010).

${ }^{13}$ A. Hautzinger, written commun., November 28, 2009.

${ }^{14}$ Wiele and others (2009).

${ }^{15}$ A. Hautzinger, written commun., November 28, 2009.

${ }^{16} \mathrm{~B}$. Moring, written commun., December 17, 2009. 
This page left intentionally blank 
Publishing support provided by the U.S. Geological Survey

Publishing Network, Tacoma Publishing Service Center

For more information concerning the research in this report, contact the Director, Washington Water Science Center

U.S. Geological Survey,

934 Broadway -Suite 300

Tacoma, Washington 98402

http://wa.water.usgs.gov/ 


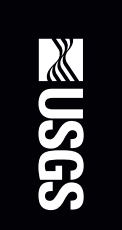

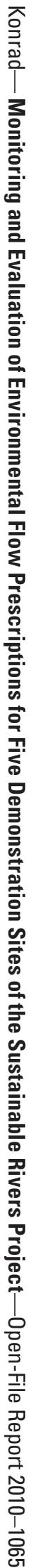

